\title{
DOES AGE STRUCTURE INFLUENCE GOLDEN-CHEEKED WARBLER RESPONSES ACROSS AREAS OF HIGH AND LOW DENSITY?
}

\author{
Hannah L. Pruett ${ }^{1}$, Ashley M. Long ${ }^{2}$, Heather A. Mathewson²,3, and Michael L. Morrison ${ }^{1,4}$
}

\begin{abstract}
AвSTRACT.-Age-based differentiation in the timing of avian migration can influence subsequent habitat use and, therefore, reproductive success. Over 2 breeding seasons, we compared arrival dates, pairing success, and fledging success for second-year (SY) and after-second-year (ASY) federally endangered Golden-cheeked Warblers (Setophaga chrysoparia) occupying areas of low $(n=9$ sites) and high $(n=10$ sites) warbler density. Male warblers arrived on low-density sites on average 6 days later (11 March) than high-density sites (5 March). Male warblers that established territories on low-density sites tended to be younger than male warblers that established territories on high-density sites. Overall pairing and fledging success were similar across low- and high-density sites, but overall pairing and fledging success were lower for SY males compared to ASY males; no SY birds fledged young on low-density sites. We found no difference in pairing or fledging success for ASY males at low- and high-density sites. For some species, habitat that supports fewer birds may be of lower quality. However, warblers in our study area fledged young at low- and high-density sites. As such, low-density sites may fill an important role in conservation efforts for this species.
\end{abstract}

RESUMEN.-La diferenciación basada en la edad al momento de la migración de las aves puede influir en el uso posterior del hábitat y, por lo tanto, en el éxito reproductivo. Durante dos temporadas reproductivas, comparamos las fechas de llegada, el éxito de apareamiento y el éxito de volantones del nido en el segundo año, y después del segundo año, del chipe dorsinegro (Setophaga chrysoparia) en peligro de extinción, ocupando áreas de baja $(n=9$ sitios $)$ y de alta $(n=10$ sitios) densidad. En promedio, los chipes dorsinegros macho llegaron a sitios de baja densidad 6 días después (11 de marzo) que a los sitios de alta densidad ( 5 de marzo). Los chipes dorsinegros macho que se establecieron en sitios de baja densidad tendieron a ser más jóvenes que los de sitios de alta densidad. En general, el éxito de apareamiento y el éxito de volantones fue similar tanto en los sitios de baja como de alta densidad, pero el éxito de apareamiento y de éxito de volantones fue menor para los chipes dorsinegros macho durante el segundo año cuando se lo comparó con el éxito que tuvieron luego del segundo año; las aves jóvenes de sitios de baja densidad no dejaron exitosamente el nido durante el segundo año. No encontramos diferencias en el éxito de apareamiento o en el éxito de volantones en aves macho en sitios de baja y de alta densidad, después del segundo año. En algunas especies, los hábitats conformados por menos cantidad de aves pueden ser de menor calidad; sin embargo, los chipes dorsinegros de nuestra área de estudio abandonaron el nido siendo jóvenes en sitios de baja y de alta densidad. Como tal, los sitios de baja densidad pueden tener un papel importante en los esfuerzos de conservación para esta especie.

Age-based differentiation in the timing of avian migration can influence subsequent habitat use and, therefore, reproductive success. Delayed migration of subadult males may result from interspecific competition on the wintering grounds for food resources if younger males do not have sufficient energy to migrate as early as their older counterparts (Marra et al. 1998, Stewart et al. 2002). Younger males may also migrate to the breeding grounds later when food resources are better (Francis and Cooke 1986, Stewart et al. 2002) and the potential for encountering harsh springtime conditions (e.g., cold spring rains and wind) is relatively low. Although the causes of delayed migration of younger males are speculative, such delays can affect access to habitat on the breeding grounds whereby first-year males are excluded from locations occupied by males that migrated earlier (Francis and Cooke 1986, Lanyon and Thompson 1986, Stewart et al. 2002). Additionally, older males may force younger males into areas where they are less likely to attract females (Van Horne 1983, Breitwisch 1989, Sherry and Holmes 1989, Bayne 2000). These types of age-based behavioral differences may explain why some older birds exhibit higher reproductive success than younger birds (Sæther 1990, Martin 1995, Lozano et al. 1996). Such differentiation could result in a proportion of the population that delays migration to the

\footnotetext{
${ }^{1}$ Department of Wildlife and Fisheries Sciences, Texas A\&M University, College Station, TX 77843.

${ }^{2}$ Natural Resources Institute, Texas A\&M University, College Station, TX 77843.

${ }^{3}$ Department of Wildlife, Sustainability, and Ecosystem Sciences, Tarleton State University, Stephenville, TX 76402.

${ }^{4}$ Corresponding author. E-mail: mlmorrison@tamu.edu
} 
breeding grounds only to end up in habitats where they have lower productivity. Therefore, understanding differences in habitat use and productivity across age classes may help inform conservation of prioritized species.

The Golden-cheeked Warbler (Setophaga chrysoparia, hereafter warbler) is an endangered insectivorous songbird that breeds exclusively in central Texas (Ladd and Gass 1999). Warblers require the bark of mature Ashe juniper (Juniperus ashei) for nesting (Pulich 1965, Ladd and Gass 1999). Habitat factors such as patch size (Collier et al. 2010, Butcher et al. 2010, Mathewson et al. 2012), patch configuration (Peak and Thompson 2013, 2014), canopy cover (Magness et al. 2006, Farrell et al. 2012), and tree species composition (Marshall et al. 2013) influence warbler occurrence, density, and reproductive success. For example, Butcher et al. (2010) found that small patches of habitat typically have fewer birds in them, and though warblers will pair in smaller patches, those birds that pair tend not to fledge young. In addition, Marshall et al. (2013) found that warbler reproductive success varied between warbler habitat dominated by Texas oak (Quercus buckleyi) and warbler habitat dominated by post oak (Quercus stellata), which they linked to arthropod abundance on the 2 tree species.

Jette et al. (1998) suggested that secondyear (SY) male warblers were less likely to pair than after-second-year (ASY) males, but once paired, SY and ASY males exhibited similar fledging success. Researchers for the City of Austin (2013) found that sites with relatively lower warbler densities $(<0.10$ territories/ha) had a higher proportion of SY males than sites with higher densities. They also showed that although pairing success was similar, fledging success was substantially lower on low-density sites compared to all sites combined. Thus, because there is evidence to suggest that warbler habitat use and reproductive success vary by bird age and site density, more detailed information on how age structure influences warbler responses in areas of high and low warbler density may assist with recovery efforts for this species.

We first used knowledge of warbler-habitat relationships to locate sites we predicted would have low and high warbler density. Over 2 breeding seasons, we collected data to confirm warbler density at our sites, to identify timing of arrival on our low- and highdensity sites, and to estimate warbler pairing and fledging success in relation to age at our low- and high-density sites. We predicted that ASY males would arrive on the breeding grounds first and select areas of high density, resulting in a higher proportion of ASY males on sites with high warbler density. We hypothesized that sites with high warbler density would also satisfy the conditions of high habitat quality (e.g., large patch size, high tree density), which would result in higher pairing and fledging success on high-density sites. Conversely, we predicted that SY males would arrive later on the breeding grounds, resulting in a higher proportion of SY males on sites with low warbler density. We hypothesized that if warbler density and habitat quality were positively related, male warblers on lowdensity sites would have lower pairing and fledging success compared to warblers at high-density sites.

\section{Methods \\ Study Area}

We conducted our study in east central Texas along the eastern portion of the warbler's breeding range. In 2012, we located sites (see below) in Bell County, within the Cross Timbers and Prairies ecoregion, an area characterized by limestone-capped buttes and mesas interspersed with grassland savannahs and woodland (Butler 2014). Tree species common to warbler habitat in this region include Ashe juniper, Texas oak, live oak (Quercus virginiana), and various other hardwoods (Hatch 2014). In the Cross Timbers and Prairies ecogion, mean temperatures during the warbler breeding season (March-June) typically range from $14.8^{\circ} \mathrm{C}$ to $26.7{ }^{\circ} \mathrm{C}$, and cumulative precipitation during this period averages $31.2 \mathrm{~cm}$ (NOAA 2014).

During the second year of our study (2013), we located sites (see below) in Travis and Hays counties within the Edwards Plateau ecoregion, an area characterized by steep limestone hills and woodlands. Woody vegetation on the Edwards Plateau is dominated by Ashe juniper, live oak, shin oak (Quercus sinuata), and mesquite (Prosopis glandulosa) (Hatch 2014). During the warbler breeding season, mean temperatures in this ecoregion typically range from $15.2{ }^{\circ} \mathrm{C}$ to $26.3{ }^{\circ} \mathrm{C}$, and 
cumulative precipitation during this period averages $36.3 \mathrm{~cm}$ (NOAA 2014).

We selected sites in different regions each year to increase our sample size (independent sites) in order to potentially observe a wider range of responses from warblers (e.g., warbler responses to habitat-specific covariates not measured, such as variation in vegetation characteristics or predator assemblage), thus further expanding the applicability of our results.

\section{Site Selection}

A habitat model developed by Collier et al. (2012) assigned predicted patch occupancy values to all habitat patches within the warbler's breeding range based on the associated patch size and landscape composition. We used this model to select patches of warbler habitat that we predicted would have low and high densities of warblers during our study. Because site occupancy by the Goldencheeked Warbler substantially declines when habitat patches are $<20$ ha (Baccus et al. 2007, Butcher et al. 2010), all patches included in our initial selection process were $>20$ ha and had a minimum predicted occupancy of 0.60 as identified by Collier et al. (2012). We chose 0.60 because we wanted to limit our surveys to patches where warblers would likely occur but not necessarily occur in high numbers at all sites.

Proximity to occupied patches can also influence whether warblers occupy a patch, because males of this species are more likely to establish territories near other males (Campomizzi et al. 2008, Farrell et al. 2012). In addition, small patches of warbler habitat are more likely to be occupied if they are close to larger occupied patches (USFWS 1996, Peterson 2001, TNC 2002, Mathewson et al. 2012). Furthermore, the approximate distance at which songs can be heard by conspecifics is $250 \mathrm{~m}$. As such, patches we identified for potential inclusion in our study were also at least $250 \mathrm{~m}$ from a patch $>200$ ha to limit potential influences of conspecific attraction and the aforementioned factors related to patch proximity (Naguib 1996, Forman 2000, Farrell et al. 2012).

After implementing selection criteria associated with the probability of occurrence, patch size, and distance to the nearest patch, we further predicted which patches would have low and high warbler density using habitat characteristics known to influence warbler productivity. In a portion of the warbler's breeding range that includes our 2012 study area in Bell County, Marshall et al. (2013) found that ecosite (i.e., land units that share similar soils and vegetation) was the best predictor of warbler productivity. More specifically, they found that warbler territories located on Low Stony Hill ecosites had up to $30 \%$ higher productivity than warbler territories established on Redlands ecosites. Thus, we used ecosite to assist with patch selection in this region. Ecosite delineations in Travis and Hays Counties are less discrete than in Bell County, so we used information on the presence and number of male warblers detected during previous studies (Pruett et al. 2013, Robinson 2013) to assist with patch selection in this region.

Given these selection criteria, in 2012 the patches we predicted would have low warbler density had a predicted probability of occurrence $>0.60$ (Collier et al. 2012), were 20-100 ha, were at least $250 \mathrm{~m}$ from a patch $>200$ ha, and occurred on Redlands ecosites. Application of these criteria to the landscape resulted in 10 patches with predicted low density, and we received permission from landowners to access 4 of those patches. In some instances, the patches spanned more than one property and we were not able to access the entire patch. Therefore, we use the term "site" to indicate the area surveyed within a patch (i.e., $n=4$ low-density sites in $2012 ; \bar{x}=81$ ha). In 2013, the patches we predicted would have low warbler density were similar with regard to the probability of occupancy, patch size, and distance from the nearest patch. They also had a relatively small number of warblers based on previously collected data (Pruett et al. 2013, Robinson 2013). Application of the selection criteria resulted in 12 patches, and we surveyed 9 low-density sites in $2013(\bar{x}=36 \mathrm{ha})$.

There are often a large number of warblers within large contiguous habitat patches. As such, the patches we predicted would have high density in 2012 had a predicted probability of occurrence $>0.60$ (Collier et al. 2012), were $>1000 \mathrm{ha}$, were at least $250 \mathrm{~m}$ from a patch $>200$ ha, and occurred on Low Stony Hill ecosites. Within each of these patches we randomly selected four 81-ha high-density 
sites to correspond with the number and mean size of low density sites we selected in 2012 . Because warblers are sensitive to edge effects (Peak 2007, Peak and Thompson 2013, 2014), all high-density sites were $\geq 100 \mathrm{~m}$ away from the edge of the patch. We used similar patch selection criteria for high-density sites in 2013, but we used previously collected data instead of ecosite delineations to predict which patches would have high warbler density. Application of the criteria to the landscape resulted in seven 36-ha sites within the Barton Creek Habitat Preserve (>1600 ha) in Austin, Texas.

Temperatures in 2012 were on average $3.4^{\circ} \mathrm{C}$ warmer than average $\left(17.2^{\circ} \mathrm{C}\right.$ to $29.7^{\circ} \mathrm{C}$, NOAA 2014; Pruett 2014, fig. 2). In 2012, precipitation in March $(20.5 \mathrm{~cm})$ was 4 times as much as the average rainfall $(5.1 \mathrm{~cm})$ for that month over the past 67 years, and April was drier than observed in historical records (NOAA 2014; Pruett 2014, fig. 3). In 2013, temperatures were $1.6{ }^{\circ} \mathrm{C}$ warmer than previously observed averages; however, precipitation in 2013 was $8.1 \mathrm{~cm}$ below average (NOAA 2014).

\section{Arrival Date}

We surveyed each site daily at the beginning of each warbler breeding season to determine male arrival dates. The earliest documented arrival of male warblers at the breeding grounds is 28 February at Fort Hood (Groce et al. 2010). Therefore, we began our daily surveys on 29 February 2012 and 25 February 2013. During our daily surveys, we walked parallel transects spaced approximately $150 \mathrm{~m}$ apart across each site. We recorded the date and location where we first detected a male warbler within the site, and we ceased daily surveys after each initial detection. We continued to survey sites every 7-10 days to locate individual warblers for banding, territory mapping, and territory monitoring activities (see below). We considered the site occupied if we detected at least one male within the site. We considered the site unoccupied if we did not detect a male warbler within one month of daily surveys.

\section{Banding and Aging}

We began target-netting male warblers upon initial detection at a site. We used territorial songs to attract males to the net. We did not attempt to capture an individual male warbler for more than $30 \mathrm{~min}$ as specified by our USFWS permit (TE195248-6). We banded birds with a USGS aluminum band and up to 3 colored plastic bands. This resulted in a unique band color combination for each banded bird, which facilitated identification of warblers throughout the season. We aged individuals in-hand using plumage characteristics described by Pyle (1997). We continued banding until we had marked all birds in each study site or until 1 June because warblers may complete their first prebasic molt within a month of fledging young (Gass 1996).

\section{Confirmation of Site Categorizations}

We used point counts in 2012 and territory mapping in 2013 to determine whether our predictions regarding warbler density at our study sites were correct. We did not conduct point counts in 2013 because we were able to map and monitor all males in each of our study sites (see below), making estimations of warbler density unnecessary. From mid-March to mid-April in 2012, we conducted 4 singleobserver point counts at point count stations that we systematically distributed across each site. Each point count station was $\geq 350 \mathrm{~m}$ from the nearest other station and at least $100 \mathrm{~m}$ from the edge of the patch (Collier et al. 2010). This resulted in 5-8 point count stations on our 4 low-density sites and 5 point count stations on each of our 4 high-density sites. During point counts, we recorded the distance $(m)$ and direction (degrees) to each male warbler that we detected within a 100-mradius circle over a 5-min survey period. To calculate density from point count data collected in 2012, we divided the total number of male warblers detected per point count by the area of the point count circle (3.14 ha). We then calculated average warbler density across the number of visits per point (i.e., 4). Next, we calculated average warbler density across points to obtain a warbler density estimate for each site.

In both years, we began territory mapping and monitoring in mid-March once behavioral observations indicated that male warblers had established territories (e.g., presence of a female). We visited each territory every 7 to 10 days until behavioral observations (e.g., no food carrying) indicated that breeding activities were complete (late June/early July). In 2012, we mapped and monitored all males 
identified at our 4 low-density sites. Given the size of $(\bar{x}=81 \mathrm{ha})$ and the large number of birds on our high-density sites, in 2012 we randomly selected approximately $25 \%$ of the total number of males identified on our 4 high-density sites to map and monitor for the purposes of this project. In 2013, we mapped and monitored all males identified on our 9 low-density and 7 high-density sites. During each territory mapping and monitoring visit in 2012 and 2013, we recorded the location of each male using a handheld Global Positioning System (GPS) unit every 2 min for as long as we could maintain visual contact with the bird or for a maximum of $30 \mathrm{~min}$. We ceased mapping activities when we observed $\geq 1$ fledgling with an adult in the territory. We used our GPS locations to construct minimum convex polygons (MCP) for each territorial male monitored in 2012 and 2013. In 2013, we calculated male warbler density as the number of MCPs divided by the area of the site.

During our territory mapping activities, we recorded behavioral observations of birds to determine the reproductive status of each territorial male (e.g., Marshall et al. 2013, Stewart et al. 2014). We also opportunistically searched for nests in each territory to supplement our behavioral observations. We considered males observed in the same location for more than 4 weeks to have successfully established a territory. We considered males paired if we observed a female with the male within an established territory. We also considered males paired if we observed evidence of nest building within the established territory (i.e., food carrying or nest material carrying by either sex). We considered males reproductively successful if we observed the male or pair with $\geq 1$ fledgling at least once during our territory mapping and monitoring visits. We calculated pairing success by dividing the number of territorial males observed with a female by the total number of territories at the site. We calculated fledging success by dividing the number of territories that fledged young by the total number of territories at the site.

\section{Data Analysis}

We pooled most data we collected in 2012 and 2013 for analyses purposes because we assumed if age-based behavioral differentiation occurred it would be evident regardless of spatial or temporal factors at our study sites. Weather patterns varied from historical weather patterns for the study sites. However, they did not occur outside the normal range of conditions (Pruett 2014). We set $\alpha=0.05$ and used R software (R Core Team 2013) for all statistical tests.

We considered low-density sites to have a warbler density $<0.10$ male warblers/ha. We first calculated warbler density and reassigned sites to the appropriate low $(\leq 0.10)$ or high $(>0.10)$ category if our site selection assumptions were incorrect. For this step, we examined density data separately for 2012 and 2013, given the differences in estimation methods between the 2 years (Zar 1999). For each year, we present the mean, range, and magnitude of difference between the low- and high-density sites. We used a $t$ test to compare mean warbler arrival dates (formatted as Julian dates) to sites with low and high warbler density (Zar 1999, pp. 122-129). We could not examine age of the first birds that arrived to each site because we did not have enough field effort to capture and age every bird as it arrived while continuing to monitor other sites for warbler arrival dates. We used Fisher's exact test to compare the ratio of SY to ASY males at sites with low and high density (Zar 1999, pp. 543-555). We used Fisher's exact tests to compare the ratios of pairing and fledging success for SY and ASY males and to compare the ratios of pairing and fledging success for SY and ASY males on sites with low and high densities (Zar 1999, pp. 543-555).

\section{Results}

\section{Site Selection}

In 2012, our site selection criteria accurately identified sites with low and high densities. However, we excluded 3 sites we predicted to have low male warbler density because we did not detect any warblers on the sites during transect surveys. Using our point count data, we estimated that the low-density site had 0.08 male warblers/ha and that the 4 highdensity sites had an average of 0.37 male warblers/ha (range 0.30-0.46 male warblers/ha). As such, high-density sites had about 4.6 times more male warblers than the low-density site. In 2013, we excluded one site we predicted would have low male warbler density because we did not detect any warblers during our 
transect surveys. In addition, 3 of the 7 sites we predicted would have high density had $\leq 0.10$ male warblers/ha and 2 of the sites we predicted would have low density had $>0.10$ male warblers/ha. We recategorized our sites accordingly. Mean male warbler density at our 8 low-density sites was 0.05 male warblers/ha (range 0.03-0.10 male warblers/ha) and mean male warbler density at our 6 high-density sites was 0.17 male warblers/ha (range 0.14-0.19 male warblers/ha). As such, high-density sites had approximately 3.4 times more male warblers than low-density sites. We pooled data across years for subsequent analyses, resulting in comparisons between 9 low-density sites and 10 high-density sites.

\section{Arrival Date}

In both years, we detected (first sightings) male warblers on high-density sites (2 March 2012 and 28 February 2013) before we detected them on low-density sites (7 March 2012 and 6 March 2013). On average, male warblers arrived at high-density sites 6 days earlier than they arrived at low-density sites $(t=-3.96, \mathrm{df}=16.43, P<0.01$; Pruett 2014, fig. 4).

\section{Banding and Aging}

We banded and aged 18 male warblers as ASY (7 in 2012, 11 in 2013) and 12 male warblers as SY (7 in 2012, 5 in 2013). We caught most birds $(73 \%)$ on high-density sites and the remaining birds on low-density sites. We found no significant difference in the proportion of SY to ASY males between sites with low and high warbler densities $(P=0.21)$.

\section{Productivity Estimate}

We monitored 86 warbler territories across 19 sites, which included 17 territories on lowdensity sites and 69 territories on high-density sites. Overall pairing success was higher on high-density sites (80\%) compared to lowdensity sites $(65 \%)$, but the difference was not statistically significant $(P=0.21)$. The proportion of territories that fledged young was similar on low- $(59 \%)$ and high-density sites $(59 \%)(P=1.0)$. We aged 26 (9 SY males and 17 ASY males) of the 86 territorial males. Overall pairing success for SY males (44\%) was significantly lower than pairing success for ASY males $(80 \%)(P=0.03)$. Overall fledging success for SY males (22\%) was also sig- nificantly lower than fledging success for ASY males $(71 \%)(P=0.04)$. None of the $4 \mathrm{SY}$ males on low-density sites paired, and 4 of 5 SY males $(80 \%)$ on high-density sites paired. Though the difference in pairing success for SY males on low-density sites (0\%) compared to SY males on high-density sites $(80 \%)$ was statistically significant $(P=0.05)$, and the difference in fledging success for SY males on low-density sites (0\%) compared to SY males on high-density sites $(40 \%)$ was not significant $(P=0.44)$, no SY birds fledged young on lowdensity sites. All 3 ASY males on low-density sites paired and $86 \%$ of ASY males on highdensity sites paired. Two of the 3 ASY males that paired on low-density sites fledged young (67\%) and $71 \%$ of ASY males on high-density sites fledged young. We found no difference in pairing $(P=1.0)$ or fledging success $(P=0.52)$ for ASY males at low- and high-density sites.

\section{Discussion}

Golden-cheeked Warblers are similar to other passerine species that show differences in reproductive success by age (Sæther 1990, Martin 1995, Lozano et al. 1996). We found that older males had higher pairing and fledging success than their younger counterparts. Additionally, warbler density at our study sites appeared to influence the pairing success of warblers based on their age, whereby young males experienced a disadvantage regarding pairing success. However, males of both age classes inhabited low-density patches during the breeding season, and we found no differences in the age structure or fledging success of SY and ASY warblers between our study sites. Although our sample size was low, our results indicate that low-density sites may fill an important role in conservation efforts for this species.

Warblers, like most bird species, display biparental care of young (Gass 1996), and passerine nests with higher male involvement have higher fledging success (Møller 2000). Lozano et al. (1996) suggested that the lower productivity of SY male American Redstarts (Setophaga ruticilla) was due to their lack of local knowledge to assist in territory placement. Because they arrive on the breeding grounds later, SY males initiate nesting behaviors later and this may reduce the number of possible nesting attempts (Lozano et al. 1996). Other 
studies have also suggested that productivity might improve with age due to overall improvements such as foraging efficiency, intraspecific competition, or predator avoidance ( $\mathrm{Nol}$ and Smith 1987, Daunt et al. 2007) that then enables the male to expend energy on attending to nestlings.

Our data show that ASY males were equally capable of pairing and fledging young on low-density sites and high-density sites. However, SY males did not fledge any young on low-density sites because they did not attract a female. SY males only contributed to the next generation when they established territories on high-density sites. This suggests a pattern of decreased pairing success for young males on sites with low density, indicating that it is not only the age of the male but also where the male establishes a territory that can determine whether his breeding season is successful. More data would help elucidate this pattern.

Although male age apparently influenced the success of each breeding attempt, the age of the female may also influence productivity. Females may use criteria independent from males, such as potential for nest predation, forage availability, or competition, to select breeding sites, which could subsequently influence the pairing success of male birds (Fontaine and Martin 2006). Female Goldencheeked Warblers select the nesting sites within the territories (Ladd and Gass 1999), and the experience of the female may influence her nest placement decisions. Each nest placement would be subjected to different levels of vulnerability to predation, which would lower productivity, or proximity to foraging substrate, which may increase the birds' productivity. Female selection decisions are not well studied due to the low detection rates of female warblers (Hayden and Tazik 1991, Jette et al. 1998); however, this information is likely relevant to all productivity measures for the species.

The arrival date of warblers on our study sites was characteristic of previously documented patterns of warbler arrival. Earlyarriving warblers have been observed as early as 28 February on Fort Hood but usually arrive in early to mid-March (Groce et al. 2010). However, we additionally observed that warblers arrived on high-density sites before they were observed on low-density sites.
This indicates that a particular suite of site characteristics made those sites more attractive to male warblers than low-density sites occupied later in the season. Local knowledge may play a role in male settlement decisions since ASY males typically display high site fidelity and have been observed returning to the same breeding areas as they used in previous years (Maas 1998, City of Austin 2013), but SY males have been observed dispersing long distances away from their hatching-year (HY) sites (Jette et al. 1998, Maas 1998, City of Austin 2013). Because productivity increases with increasing patch size (Coldren 1998, Butcher et al. 2010), large patches may be occupied first. Maas (1998) found that afterhatching-year (AHY) birds are more likely to return to large patches (>700 ha), although there is no information on whether previous years' breeding success influences future settlement decisions (Groce et al. 2010). Conspecific attraction may also play a role in male site selection (Farrell et al. 2012) as males tend to settle near other males, so high-density sites may be more likely to attract additional males than an empty patch of potential habitat.

Rockwell et al. (2012) cited numerous studies that reported a negative relationship between delayed arrival and reproductive success. Although we did not collect data on the age of the first bird to arrive to each study site, we did find differences in arrival based on territory density within the study site. We did not find differences in reproductive success though, which suggests that despite delayed arrival to the low-density sites, productivity was not influenced by that delay.

Roughly $90 \%$ of the patches in the warbler's breeding range have a low predicted occupancy (Collier et al. 2012), and many of these patches are relatively small. Typically, it is recommended to maintain large patches of habitat to support sustainable breeding populations of warblers; however, warblers are not restricted from breeding on smaller patches (Butcher et al. 2010). Additionally, Farrell et al. (2012) showed that Golden-cheeked Warblers can be induced to occupy and then successfully breed on low-density sites (see also Campomizzi et al. 2008). Our research indicates that older males have similar territory success regardless of differences in territory density. In places where older males established territories, they were able to successfully 
breed. So, although it is important to maintain large tracts of potential habitat, smaller patches are also utilized by breeding warblers and should be considered in conservation planning across broad spatial extents.

\section{ACKNOWLEDGMENTS}

We thank the U.S. Army Integrated Training Area Management (ITAM) Program, Office of the Secretary of Defense, Department of Defense, for providing funding support, with additional support from the Texas Department of Transportation and Texas Ecolab. We thank the numerous landowners, including The Nature Conservancy, Austin, who permitted us access to their property, and the many field technicians who assisted with data collection. We thank personnel of the Texas A\&M Natural Resources Institute, particularly T. McFarland, for technical, logistical, and administrative support. H. Pruett also thanks David M. Cairns for his guidance throughout her graduate studies. Our manuscript was improved by comments from 2 journal reviewers.

\section{Literature Cited}

Baccus, J.T., M.E. Tolle, and J.D. Cornelius. 2007. Response of Golden-cheeked Warblers (Dendroica chrysoparia) to wildfires at Fort Hood, Texas. Occasional Publication of the Texas Ornithological Society $7: 1-37$.

BAYNE, E.M. 2000. Effects of forest fragmentation on the demography of Ovenbirds (Seiurus aurocapillus) in the boreal forest. Doctoral dissertation. University of Saskatchewan, Saskatoon, SK, Canada.

Breitwisch, R. 1989. Mortality patterns, sex ratios, and parental investment in monogamous birds. Pages 1-50 in D.M. Power, editor, Current Ornithology. Plenum Press, New York, NY.

Butcher, J.A., M.L. Morrison, D. Ransom JR., R.D. SLACK, AND R.N. Wilkins. 2010. Evidence of a minimum patch size threshold of reproductive success in an endangered songbird. Journal of Wildlife Management 74:133-139.

ButLer, D.R. 2014. Environment: physical regions. Pages 79-84 in E.C. Alvarez and R. Plocheck, editors, Texas Almanac 2014-2015. Texas State Historical Association, Denton, TX.

Campomizzi, A.J., J.A. Butcher, S.L. Farrell, A.G. SnelGROVE, B.A. COLLIER, K.J. GUTZWILler, M.L. MORRISON, AND R.N. WILKINS. 2008. Conspecific attraction is a missing component in wildlife habitat modeling. Journal of Wildlife Management 72:331-336.

City of Austin. 2013. 2013 Annual report: Goldencheeked Warbler (Dendroica chrysoparia) monitoring program. Balcones Canyonlands Preserve. City of Austin Water Utility, Wildland Conservation
Division, and Balcones Canyonlands Preserve Program.

Coldren, C.L. 1998. The effects of habitat fragmentation on the Golden-cheeked Warbler. Doctoral dissertation, Texas A\&M University, College Station, TX.

Collier, B.A., J.E. Groce, M.L. Morrison, J.C. Newnam, A.J. Campomizzi, S.L. Farrell, H.A. Mathewson, R.T. Snelgrove, R.J. Carroll, and R.N. Wilkins. 2012. Predicting patch occupancy in fragmented landscapes at the rangewide scale for an endangered species: an example of an American warbler. Diversity and Distributions 18:158-167.

Collier, B.A., M.L. Morrison, S.L. Farrell, A.J. Campomizzi, J.A. Butcher, K.B. Hays, D.I. MacKenzie, AND R.N. WiLKIns. 2010. Monitoring endangered species occupying private lands: case study using the Golden-cheeked Warbler. Journal of Wildlife Management 74:140-147.

Daunt, F., S. Wanless, M.P. Harkis, L. Money, and P. MONAGHan. 2007. Older and wiser: improvements in breeding success are linked to better foraging performance in European Shags. Functional Ecology 21:561-567.

Farrell, S.L., M.L. Morrison, A. Campomizzi, and R.N. WiLKIns. 2012. Conspecific cues and breeding habitat selection in an endangered woodland warbler. Journal of Animal Ecology 81:1056-1064.

Fontaine, J.J., and T.E. Martin. 2006. Habitat selection response of parents to offspring predation risk: an experimental test. American Naturalist 168:811-818.

Forman, R.T. 2000. Estimate of area affected ecologically by the road system in the United States. Conservation Biology 14:31-35.

Francis, C.M., AND F. CoOKe. 1986. Differential timing of spring migration in wood warblers (Parulinae). Auk 103:548-556.

Gass, L.R. 1996. Nesting behavior of Golden-cheeked Warblers in Travis County, Texas. Master's thesis, Southwestern Texas State University, Austin, TX.

Groce, J.E., H.A. Mathewson, M.L. Morrison, and N. WILKINS. 2010. Scientific evaluation for the 5-year status review of the Golden-cheeked Warbler. Institute of Renewable Natural Resources, College Station, TX.

Hatch, S.L. 2014. Texas plant life. Pages 114-117 in E.C. Alvarez and R. Plocheck, editors, Texas Almanac 2014-2015. Texas State Historical Association, Denton, TX.

Hayden, T.J., and D.J. Tazik. 1991. Project status report: 1991 field studies of two endangered species (the Black-capped Vireo and the Golden-cheeked Warbler) and the cowbird control program on Fort Hood, Texas. U.S. Army Construction Engineering Research Laboratory, Fort Hood, TX.

Jette, L.A., T.J. Hayden, and J.D. Connelius. 1998. Demographics of the Golden-cheeked Warbler (Dendroica chrysoparia) on Fort Hood, Texas. U.S. Army Corps of Engineers Technical Report 98/52.

LADD, C.G., AND L. GaSs. 1999. Golden-cheeked Warbler (Dendroica chrysoparia) in A. Poole, editor, The Birds of North America Online. Cornell Lab of Ornithology, Ithaca, NY.

LANYON, S.M., AND C.F. ThOMPSON. 1986. Site fidelity and habitat quality as determinants of settlement pattern in male Painted Buntings. Condor 88:206-210.

Lozano, G.A., S. Perreault, and R.E. Lemon. 1996. Age, arrival date and reproductive success of male 
American Redstarts (Setophaga ruticilla). Journal of Avian Biology 27:164-170.

MaAs, D.S. 1998. Factors influencing demographics of Golden-cheeked Warbler (Dendroica chrysoparia) at Fort Hood Military Reservation, Texas. Master's thesis, University of Oklahoma, Norman, OK.

Magness, D.R., R.N. Wilkins, and S.J. HeJl. 2006. Quantitative relationships among Golden-cheeked Warbler occurrence and landscape size, composition, and structure. Wildlife Society Bulletin 34: 473-479.

Marra, P.P., K.A. Hobson, and R.T. Holmes. 1998. Linking winter and summer events in a migratory bird by using stable-carbon isotopes. Science 282:1884-1886.

Marshall, M.E., M.L. Morrison, and R.N. Wilkins, 2013. Tree species composition and food availability affect productivity of an endangered species: the Golden-cheeked Warbler. Condor 115:882-892.

Martin, K. 1995. Patterns and mechanisms for agedependent reproduction and survival in birds. American Zoologist 35:340-348.

Mathewson, H.A., J.E. Groce, T.M. McFarland, M.L. Morrison, J.C. Newnam, R.T. Snelgrove, B.A. ColLIER, AND R.N. WILKINS. 2012. Estimating breeding season abundance of Golden-cheeked Warblers in Texas, USA. Journal of Wildlife Management 76: $1117-1128$.

MøLler, A.P. 2000. Male parental care, female reproductive success, and extrapair paternity. Behavioral Ecology 11:161-168.

NaGuib, M. 1996. Auditory distance estimation in songbirds: implications, methodologies, and perspectives. Behavioral Processes 38:163-168.

[NOAA] National OCEANic and ATMOSPheric AdminisTRATION. 2014. National Climate Data Center Online. USDC, National Climatic Data Center, Asheville, NC; [accessed 1 February 2014]. http://www.ncdc noaa.gov/

Nol, E., AND J.N.M. Smith. 1987. Effects of age and breeding experience on seasonal reproductive success in the Song Sparrow. Journal of Animal Ecology 56:301-313.

PEAK, R.G. 2007. Forest edges negatively affect Goldencheeked Warbler nest survival. Condor 109:628-637.

PEAK, R.G., and F.R. Thompson III. 2013. Amount and type of forest cover and edge are important predictors of Golden-cheeked Warbler density. Condor 115:659-668.

PEak, R.G., AND F.R. Thompson III. 2014. Seasonal productivity and nest survival of Golden-cheeked Warblers vary with forest type and edge density. Condor 116:546-559.

Peterson, C.E. 2001. Golden-cheeked Warbler (Dendroica chrysoparia: Parulidae) territory and non-territory habitat choice in fragmented Ashe juniper patches on the Kerr Wildlife Management Area. Master's thesis, Southwest Texas State University, San Marcos, TX.

PruetT, H.L. 2014. Age structure of Golden-cheeked Warblers in areas of low abundance. Master's thesis, Texas A\&M University, College Station, TX.
Pruett, H.L., H.A. Mathewson, and M.L. Morrison. 2013. Study of the potential impacts of highway construction on selected birds with emphasis on the Golden-cheeked Warbler: annual report 2013. Texas A\&M Institute of Renewable Natural Resources, College Station, TX.

Pulich, W.M. 1965. The Golden-cheeked Warbler of Texas. Audubon Field Notes 19:545-548.

PYLE, P. 1997. Golden-cheeked Warbler. Pages 478-480 in Identification guide to North American birds. Part 1. Slate Creek Press, Bolinas, CA.

R Core Team. 2013. R: a language and environment for statistical computing. R Foundation for Statistical Computing, Vienna, Austria. http://www.R-project.org

Robinson, D.H. 2013. Effects of habitat patch size on occupancy and reproductive success of a forestdependent songbird in an urban landscape. Master's thesis. Texas A\&M University, College Station, TX

Rockwell, S.M., C. WE. BocetTI, AND P.P. Marka. 2012. Carry-over effects of winter climate on spring arrival date and reproductive success in an endangered migratory bird, Kirtland's Warbler (Setophaga kirtlandii). Auk 129:744-752.

SÆTHeR, B. 1990. Age-specific variation in reproductive performance of birds. Current Ornithology 7:251-283.

Sherry, T.W., AND R.T. Holmes. 1989. Age-specific social dominance affects habitat use by breeding American Redstarts (Setophaga ruticilla) - a removal experiment. Behavioral Ecology and Sociobiology 25: 327-333.

Stewart, L.R., M.L. Morrison, M.R. Hutchinson, D.N. APPEL, AND R.N. WILKINS. 2014. Effects of a forest pathogen on habitat selection and quality of the endangered Golden-cheeked Warbler. Wildlife Society Bulletin 38:288-296.

Stewart, R.L.M., C.M. Francis, and C. Massey. 2002. Age-related differential timing of spring migration within sexes in passerines. Wilson Bulletin 114: 264-271.

[TNC] The Nature Conservancy. 2002. A range-wide assessment of potential breeding habitat for the Golden-cheeked Warbler-final report. San Antonio, TX.

[USFWS] United States Fish and Wildlife Service. 1996. Golden-cheeked Warbler population and habitat viability assessment report. C. Beardmore, J. Hatfield, and J. Lewis, editors. Report of an August 21-24, 1995 workshop arranged by the U.S. Fish and Wildlife Service in partial fulfillment of U.S. National Biological Service Grant No. 80333-1423. Austin, TX. xii + 48 pp. + Appendix.

VAn HoRne, B. 1983. Density as a misleading indicator of habitat quality. Journal of Wildlife Management 47:893-901.

ZaR, J.H. 1999. Biostatistical analysis. 4th edition. Prentice Hall, Upper Saddle River, NJ.

Received 8 June 2017 Accepted 23 August 2017

Published online 31 December 2017 